FIXING SEX 



\section{FIXING SEX}

Intersex, Medical Authority,

and Lived Experience

\section{KATRINA KARKAZIS}

DUKE UNIVERSITY PRESS

Durham and London

2008 
(C) 2008 DUKE UNIVERSITY PRESS

All rights reserved

Printed in the United States

of America on acid-free paper $\infty$

Designed by Amy Ruth Buchanan

Typeset in Quadraat by Keystone

Typesetting, Inc.

Library of Congress Cataloging-in-

Publication Data appear on the last printed page of this book. 
To my family, for everything

And to Carole, Suzanne, and Bo, without whom ... 

Do we truly need a true sex? With a persistence that borders on stubbornness, modern Western societies have answered in the affirmative. ... For a long time, however, such a demand was not made. . . . Indeed, it was a very long time before the postulate that a hermaphrodite must have a sex-a single, a true sex-was formulated. -MICHEL FOUCAULT, introduction to Herculine Barbin: Being the Recently Discovered Memoirs of a Nineteenth-Century French Hermaphrodite, I980 
